\title{
Ezekiel's "Living Beings" in Pseudo-Ezekiel 4Q385, Frg. 6: A Comparison with Key Angelological Verses in Ezekiel 1 and 10
}

\author{
AnNetTe EVAns (UNIVERSITY OF THE FREE StATE)
}

\begin{abstract}
Earlier research has demonstrated that certain ambiguous angelological phrases which hint at divinatory associations present in MT Ezek 1 and 10 (the so-called "Merkebah Chapters") have been suppressed in the LXX version. As a translation, the $L X X$ reflects the religious needs and exegetical perceptions of the Alexandrian Jews in the third and second centuries BCE. This article compares these key angelological verses in Ezek 1 and 10 with linguistically or semantically similar words or phrases in 4Q385 Pseudo-Ezekiel. The result of the comparison indicates that these telltale verses are contradicted in Pseudo-Ezekiel 4Q385 Frg. 6. The Dead Sea Scrolls share aspects and problems of beliefs in angels with the Judaism of their period, but the texts found at Qumran increase the difficulty of defining Jewish angelology, partly because of lack of knowledge concerning their provenance, and partly because the different works show quite disparate beliefs and motives concerning angels. The conclusion of this article is that Pseudo-Ezekiel was written by a conservative author who on the one hand did not want to reveal the divinatory aspects of the angelological content, but on the other hand was innovative.
\end{abstract}

Key Words: Angels; Ezekiel; Pseudo-Ezekiel; Qumran; Jewish angelology.

\section{A INTRODUCTION}

The Book of Ezekiel was written by the priest who was exiled to Tel Abib on the Chebar canal near the Babylonian city of Nippur in 598 BCE, eleven years before the final defeat of Judah. Mach's observation that whenever Jewish identity underwent a crisis "exalted angels or the like" were introduced is born out in Ezek 1 in the description of the strange "living beings" surrounding the chariot throne. ${ }^{1}$ Comparison of Ezekiel's description with the rewritten version

* Article submitted: 24/10/2016; peer-reviewed: 19/01/2017; accepted: 24/01/2017. Annette Evans, "Ezekiel’s 'Living Beings' in Pseudo-Ezekiel 4Q385, Frg. 6: A Comparison with Key Angelological Verses in Ezekiel 1 and 10,” Old Testament Essays 30/2 (2017): 300-314, doi: http://dx.doi.org/10.17159/2312-3621/2017 /v30n2a7

1 Michael Mach, Entwicklungsstadion des Jüdischen Engelglaubens in vorrabbinischer Zeit (Tübingen: Mohr, 1992), 42. Walther Zimmerli, The Fiery Throne: The Prophets and Old Testament Theology (Minneapolis: Fortress Press, 
in Pseudo-Ezekiel 4Q385 frg. 6 yields a clearer understanding of the possible significance of the "living beings," but the Qumran text provides indications that the author had a significantly different exegetical orientation. The Dead Sea Scrolls share aspects and problems of beliefs in angels with the Judaism of their period, but the Qumran settlement was "an apocalyptic group awaiting the eschaton."2 Whereas Ezekiel's original vision gave the devastated exiles in Babylon new hope, half a millennium later the Qumran sectarians awaiting the eschaton found themselves with new challenges. Spangenberg has pointed out that historical-critical studies of ancient texts should also be concerned with context, culture and worldview. ${ }^{3}$ This article explores the rhetorical and ideological orientation that the author of Pseudo-Ezekiel employed in his rewriting in order to meet the needs of his new cultural context. ${ }^{4}$

2003), 96, notes that the setting of the book of Ezekiel suggests that the Babylonian environment was probably the source of the strange apparitions in Ezekiel's visions. This observation is confirmed by Christopher Uehlinger and Susanne Müller Trufaut, "Ezekiel 1, Babylonian Cosmological Scholarship and Iconography: Attempts at Further Refinement,” TZ 2/57 (2001): 143. Iconography deriving from Mesopotamia demonstrates that cosmology and astral phenomena were a major concern of first millennium BCE in that area. Amar Annus, The God Ninurta in the Mythology and Royal Ideology of Ancient Mesopotamia (Helsinki: University of Helsinki NeoAssyrian Text Corpus Project, Institute for Asian and African Studies, 2002), 188, 191, describes a Babylonian mystical text published by A. Livingstone, Mystical and Mythological Explanatory Works of Assyrian and Babylonian Scholars (Oxford: Clarendon, 1986), 822-824 in which the god Bel is seated on a throne of lapis lazuli and surrounded by "a gleam of amber." He sees the post-exilic influence of Ninurta, "the defender of the divine world order" as the origin of the imagery of the throne vision in Ezek 1:26, 27. Livingstone, Mystical, 260, notes that the colophon of the Babylonian tablet described by Annus explicitly attests that the information on it was considered to be esoteric. P. Kingsley, "Ezekiel by the Grand Canal: Between Jewish and Babylonian Traditions" JRAS 3 (1992): 345 suggests that the secret cultural transmission from the Babylonian priestly tradition to the strongly guarded rabbinic tradition took place not by peripheral cultural contact, but from "heart" to "heart" of the esoteric tradition in both cultures.

2 Jody Magness, The Archaeology of Qumran and the Dead Sea Scrolls (Grand Rapids, MI: Williams B. Eerdmans Publishing Company, 2002), 68.

3 Izak J. J. Spangenberg, "Psalm 24: Reading from Right to Left and from Back to Front,” OTE 24 (2011): 762.

4 David J. A. Clines, "A World established on Water (Psalm 24): Reader-Response, Deconstruction and bespoke Interpretation," in The New Literary Criticism and the Hebrew Bible, ed. J. Cheryl Exum and David J. A. Clines (Sheffield: Sheffield Academic Press, 1995), 85. 


\section{B METHODOLOGY}

This article compares the underlying angelological content of the description of the "living beings" in MT and LXX Ezek 1 and 10 with the same subject in 4Q385 fragment 6. Lines 5-11 of Frg. 6 are the immediate focus of this article, but when the conclusion is formulated, their context in the entire text is taken into consideration. The methodological assumption is that the author of Pseudo-Ezekiel selected from Ezekiel's book what he regarded as relevant in his own new and different cultural context, and constructed his text in such a way that it reflects his own interpretation of Ezekiel's vision. Dimant and Strugnell's summary of the interpretive methods of the author recognised substitution of biblical terms by nonbiblical ones, and small interpretive additions. ${ }^{5}$ I see these later interpretations not only as pointers to the author's ideological orientation, but also as providing fresh insight into the potential that Ezekiel's original vision contained. In rewriting Ezekiel's vision, the author of PseudoEzekiel recognised the need for re-examination of his current concept of God, as does Spangenberg two thousand years later. ${ }^{6}$

As a foundation for comparison, the underlying angelological content in Ezek 1 and 10, which I had identified in my dissertation, was used. ${ }^{7}$ Because the MT as presented in BHS is based on the tenth century CE Codex St. Petersburg, recourse had to be taken to the much earlier Septuagint, which, when closely read, contributes significantly to the understanding of these mysterious biblical texts. Uncial B, dated to the 4th century CE has been "tacitly assumed" to be the Septuagint, and was the principal source for Rahlf's LXX, but Rahlf's text is eclectic and he frequently corrected the Greek using Codex Sinaiticus and Codex Alexandrinus. ${ }^{8}$ Currently, the best reconstruction of the LXX is Ziegler's Göttingen edition, revised in 1977, in which Ms Vaticanus and Pap. 967 (the pre-Hexaplaric Chester-Beatty - John H. Scheide fragments of Ezekiel) were the main witnesses, but unfortunately Ezek 1 to 11 are not extant in this earliest witness. ${ }^{9}$ Johan Lust agrees with Ziegler that

5 Devorah Dimant and John Strugnell, “The Merkebah Vision in Second Ezekiel," RevQ 14 (1990): 331-348.

$6 \quad$ See Izak Spangenberg, "The Spotlight on Genesis 1-3: A Report on Shifts in Mindset and Beliefs,” OTE 27 (2014): 632.

7 Annette H. M. Evans, "The Development of Jewish Beliefs in Angels: Egyptian and Hellenistic Connections ca. 600 BCE-ca.200 CE," (D Phil. diss., University of Stellenbosch, 2007), 262-269.

8 Johan Lust, "Translation Greek and the Lexicography of the Septuagint” JSOT 59 (1993): 118. Uncial B has been widely identified with the early Alexandrian recension of Hesychius, and is assessed by Sidney Jellicoe, The Septuagint and Modern Study (Oxford: Clarendon Press, 1968), 177, to be far from uniform in value.

9 Joseph Ziegler, ed., Ezekiel, vol. 16/1 of Septuaginta Vetus Testamentum Graecum (Göttingen: VandenHoeck \& Ruprecht, 1977). 
papyrus 967, as the shorter text, preserved the earliest text form. ${ }^{10}$ However, Tov maintains that contrary to the rule that the shorter readings are original; no short reading should automatically be considered original, because scribal omissions often cannot be distinguished easily from content omissions or additions, and all evaluation of retroversion of variants is "completely subjective."11 Halperin observed that "textual critics plausibly treat the hypothetical Vorlage of LXX as if it were a variant Hebrew manuscript reading; they sometimes argue that it is superior to MT and emend the Hebrew text accordingly," but he points out that as a translation the LXX reflects the religious needs and exegetical perceptions of Alexandrian Jews in the third and second centuries BCE. ${ }^{12}$

There have been many attempts to explain the pluses and minuses in the OG as due to glosses of various kinds during the redaction, but in his classification of the glosses in Ezek 1 to 24, Freedy reduced the number that Fohrer described in his systematisation of 1951 to less than half. ${ }^{13}$ Fishbane recognised the tendency of past scholars to isolate glosses on the basis of implicit and subjective criteria, "frequently without systematic recourse to inner or comparative textual factors." 14 Patmore suggests that the Qumran discoveries have rendered the Urtext of Ezekiel a "will-o'-the-wisp” because

10 Johan Lust, “The 'Rekenaar' and the Septuagint - LXx Ezekiel, A Case Study,” in Bible and Computer: The Stellenbosch AIB 1-6 Conference: Proceedings of the Association Internationale Bible et Informatique "From Alpha to Byte," University of Stellenbosch 17-21 July, 2000, ed. Johan Cook (Leiden: Brill, 2000), 378. Johan Lust, "The Use of Textual Witnesses for the Establishment of the Text: The Shorter and Longer Texts of Ezekiel: An Example: Ez. 7,” in Ezekiel and his Book, ed. Johan Lust (Leuven: Uitgeverij Peters, 1986), 19, concluded that the OG of Ezekiel is significantly shorter than the MT. He stated that the MT is a further developed version than the LXX, and the MT may have preserved a "final form" of the book.

11 Emmanuel Tov, The Text-Critical use of the Septuagint in Biblical Research (Jerusalem: Simor Ltd., 1981), 281, 293.

12 David J. Halperin, “Merkabah Midrash in the Septuagint” JBL 101 (1982): 351.

13 Kenneth S. Freedy, “The Glosses in Ez I - XXIV” VT 20 (1970): 130 recognises glosses as extraneous additions when they use reverse gender within the context of the account in which they are used, and suggests that these instances of reverse gender represent a scribal convention designed to call attention to the fact that the word involved is a gloss and is not intended to be considered part of the text. He labels this type a cue gloss. Most occur in Ezek 1, and have reference to the "living creatures" which are feminine in grammatical form, but masculine in physical description.

14 Michael Fishbane, Biblical Interpretation in Ancient Israel (Oxford: Clarendon Press, 1985), 41. Moshe Greenberg, Ezekiel 1-20, AB (New York: Doubleday, 1983), 133, also considers the treatment of glosses in Ezekiel in the commentaries of Georg Fohrer, Ezechiel (Tubingen: Mohr Siebeck, 1955), Walther Eichrodt, Ezekiel: A Commentary, trans. Cosslett Quinn (London: SCM Press, 1970), and especially Walther Zimmerli, Ezekiel 1: Chapters 1-24, Hermen. (Philadelphia: Fortress Press, 1979), as completely arbitrary. 
the Qumran evidence casts some instances of the currently accepted reconstruction of the OG using the traditionally "weighty" LXX sources into doubt. ${ }^{15}$

Freedy notes that although the recognition and excision of glosses in many places in MT Ezek 1 and 10 restore the syntax of the original and "this provides better access to a proper analysis and interpretation of the tradition," the insertion of glosses is a valuable indication of the nature of the tradition and manner in which it grew. ${ }^{16}$ Origen's comment reported by James Sanders that it is impossible to reconstruct an "original" text, but that it is "valuable to sift through the ruins still available to find the gold nuggets whereby God or Holy Spirit might speak to a new situation," is apt in this situation. ${ }^{17}$ For example, both the two significant vv. 14 of Ezek 1 and 10, which have not been included in the OG reconstruction because they were regarded as glosses, are attested in the Qumran fragments. ${ }^{18}$ The approach in this article is that, regardless of when exactly vv. 14 of Ezek 1 and 10 arose, the fact that they are present in fragments amongst the Qumran discoveries, provides important information on the development of Jewish beliefs about angels. In order to make a meaningful comparison, as a start, relevant angelological aspects of the four living beings in the MT and the Septuagint are considered below.

\section{ANGELOLOGICAL ASPECTS OF THE FOUR LIVING BEINGS IN EZEKIEL 1 AND 10}

Ezekiel's living beings are closely associated with huge wheels that are described as having the spirit of the living beings in them: when the unit of four living creatures rises above the earth, presumably using the unit of sixteen wings, the wheels rise with it "for the spirit of the living creatures was in the wheels” (Ezek 1:21 NRSV). In the ANE, descriptions of the lesser divinities as winged creatures are well known. ${ }^{19}$ Although in heaven, with wings, the forms of these four living beings are depicted as having human hands (וידו אדם, Ezek 1:8). They are each joined at two of their wings with the adjacent one,

15 Hector M. Patmore, “The Shorter and Longer Texts of Ezekiel: The Implications of the Manuscript Finds from Masada and Qumran” JSOT 32 (2007): 241.

16 Freedy, Glosses, 130.

17 James A. Sanders, "Origen and the First Christian Testament," in Studies in the Hebrew Bible, Qumran, and the Septuagint Presented to Eugene Ulrich, ed. Peter W. Flint, Emanuel Tov and James C. VanderKam (Leiden: Brill, 2006), 141.

18 Judith E. Sanderson, "Ezekiel," The Prophets, vol. 10 of Qumran Cave 4, ed. Eugene Ulrich, Frank Moore Cross, Russell E. Fuller, Judith E. Sanderson, Patrick W. Skehan and Emanuel Tov (Oxford: Clarendon, 1997), 211, reports that 4Q Ezekiel b Col IV Frgs 5-6 lines 1 and 2, have a space (illegible due to damage) where Ezekiel 1:14 and 15 would have been, and continues on the next line with part of Ezek 1:16, and 4Q Ezekiel a Frg. I lines 13 and 14 have the following words of Ezek 10:14: ואר]בעיח והשלשי. [.

19 E. Theodore Mullen, Jr., The Assembly of the Gods, HSM 24 (Atlanta, GA: Scholars Press, 1980), 185. 
forming a square, but it is stressed that the unit does not turn as it moves (לא יסבו בלכתן), but goes straight forward (Ezek 1:9). In v. 12 the description of the joined wings is again followed by the assertion that the living beings do not turn as they move, but go straight forward. The detail that they do not turn in their going is again stressed in v. 17b. This stress is also evident in Ezek 10:11 (twice) and 10:16. It is impossible to visualize the manner of locomotion, הבזק : 1:14 why the emphasis on not turning? A hint is contained in MT "והחיות רצוא ושוב כמראה , "And the living creatures ran and returned as the appearance of a flash lightning” (KJV; NRSV has “darted to and fro”). This crucial verse has not been included in the OG reconstruction of the LXX, but is attested in fragments of Ezekiel's book found at Qumran (see n. 15).

Jerome defended the Greek translator's exclusion of Ezek 1:14 by pointing out that it contradicts the repeated stress that the living beings do not turn as they move. ${ }^{20}$ That the absence of Ezek 1:14 was already being discussed in the early centuries of the common era reinforces that it conveyed important controversial content. In this study the 5th or 6th century Codex Alexandrinus is referred to for comparison with the Greek translation of v. 14: ka i t a $\mathbf{z}$ wa et rex on ka i a neka mpt on wj eidoj tou bezek (literally: "and the living beings ran and returned as the appearance of lightning”). It is important to note that parts of Codex Alexandrinus go back to the second century BCE; for instance the fifteen verses of Deuteronomy extant in Codex Alexandrinus show a remarkable agreement with the 2nd century BCE Rylands Papyrus Greek $458 .^{21}$

Subsequent research encompassing a broader cultural context reinforces the possibility that the elimination of Ezek 1:14 from the OG is related to the stress on not turning; under the surface of this text there are indications of divinatory activity connected to turning which may have been excised later by conservative translators or redactors. ${ }^{22}$ Comparison with the LXX version of Ezek 1 and 10 provides a hint of an undercurrent related to the denial of turning. For instance, Ezek 1:15 to 22 describe the ophanim, האופנים, which appear to be four huge wheels each standing beside each of the four living creatures, and each constructed as if it were a "wheel within a wheel." However, in ch. 10 both terms ophanim and the Aramaic word for wheel, galgal, are used, even in the same sentence; furthermore, at Ezek 10:13 at the second mention of wheels, the galgali are addressed as if animate. In this position, the word galgali is left untranslated in the LXX, suggesting an awareness that in that context, galgali have a different meaning to that of ophanim (wheels). Previous research has indicated that the "wheel within a

\footnotetext{
20 Johan Lust, “Notes to the Septuagint Ezekiel 1 and 2,” ETL 75 (1999): 17.

21 Jellicoe, Septuagint, 187.

22 Evans, "Development," 287, 288.
} 
wheel” has cosmological implications, also related to divinatory activities. ${ }^{23}$ However, just as galgali are not mentioned in Pseudo-Ezekiel, so is there no mention of "wheel within a wheel" in Pseudo-Ezekiel. The association of the four wings with wheels, (which of course imply rotational movement), and the use of the term galgali compound the association with certain divinatory activities which may have been problematic for conservative translators of the Hebrew into the Greek language (which inevitably reflects Hellenistic culture). ${ }^{24}$ Bowker observed that rabbinic Judaism attempted to suppress aspects that contained angelological or "magical" connotations. ${ }^{25}$ Halperin also observed that the Greek translators of Ezekiel (possibly in c.150 BCE) show a concern with extracting, or concealing the divinatory implications of the sacred text, as does the Targum. ${ }^{26}$

Rotational movement is a frequently described characteristic of a certain type of angelic messenger which features in the divinatory activities described in the Chaldean Oracles (i.e. the Iynges). Lewy demonstrated that the system of intermediaries in the Chaldean Oracles is derived from the Jewish system of angelology, and that this fusion of Platonism with mysticism and magic probably has its roots in earlier centuries. He describes the intermediaries (Iynges) as "fiery bodies, of the nature of lightning ... regarded as messengers of the gods ... who swiftly hasten forth from the Father and back towards Him ... leaping in tireless revolution into the worlds at the mighty command of the Father, as the thoughts of the Supreme Being: thinking through circular motion." ${ }^{27}$ The Chaldean Oracles are remnants of the oral tradition of what must have been widespread ANE divinatory activity, but they were only written down in the later Neo-Platonic context. Thus, the influence of that type of intermediary practice remained masked in earlier writings. ${ }^{28}$

23 Uehlinger and Trufaut, "Ezekiel 1,” 154, 155. Cf. Plato, Tim. 36C (Bury, RG), "And he compassed them about with the motion that revolves in the same spot continually, and He made the one circle outer and the other inner."

24 For instance Johann Cook, The Septuagint of Proverbs - Jewish and/or Hellenistic Proverbs? Concerning the Hellenistic Colouring of LXX Proverbs (Leiden: E J Brill, 1997) concluded that in the LXX of Proverbs the translator's ideology is characterised by a fundamentally conservative Jewish religious attitude.

25 John Bowker, The Targums and Rabbinic Literature (Cambridge: Cambridge University Press, 1969), 38.

26 Halperin, “Merkebah Midrash,” 363.

27 Hans Lewy, The Chaldean Oracles (Paris: Etudes Augustineinnes, 1978), $14 \mathrm{n}$. 32, 132-133, 162, 312. Also see Ruth Majercik, The Chaldean Oracles (Leiden: E. J. Brill, 1989), 215; Evans, “Development,” 230.

28 Lewy, Chaldean, 133-134. The similarity here with Ezek 1:14 is striking. In the Chaldean system the Iynges function as mediators of messengers. See Majercik, Chaldean, 9, 215; Evans, "Development," 230. According to Lewy, Chaldean, 132133, 163, the Iynges are Plato's good daemons who "interpret between gods and men, 


\section{COMPARABLE ANGELOLOGICAL ASPECTS IN Frg. 6 OF 4Q385 PSEUDO-EZEKIEL}

The hand of this copy is dated to 50-25 BCE, that is, only about a hundred years after the probable date of the Greek translation of Ezekiel. Dimant's reconstruction of the text places Frg. 6 in the final column of the text. ${ }^{29}$ The first four lines of Frg. 6 conclude a description of part of Ezekiel's vision of the Dry Bones, thereby indicating a concern with some form of resurrection. ${ }^{30}$ Strikingly, the fifth line abruptly starts with a new heading announcing Ezekiel's Merkebah vision.

Lines 5-11 as published by Dimant, together with her translation are given below.

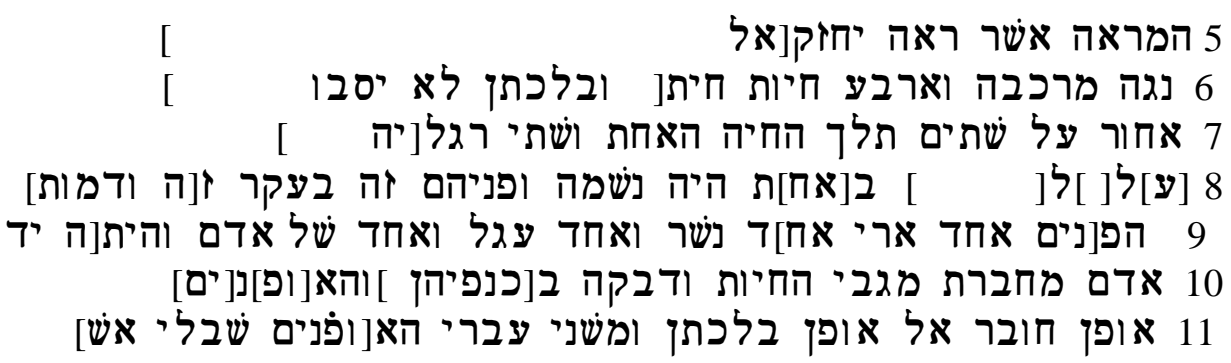

Dimant's translation of lines 5-11:

5 The vision which Ezek[iel] saw ... [ ]

6 a radiance of a chariot, and four living creatures; a living creature [ and while walking they would not turn]

7 backwards; upon two (legs) each living creature was walking. And [its] two legs [ ]

8 [up]on [ ] in [on]e there was spirit and their faces were one beside the oth[er. And the appearance of]

conveying and taking across to the gods the prayers and sacrifices of men, and to men the commands and replies of the gods” (Frg. 78; Cf. Plato, Symp., 202 E). In Frg. 87 the activities of the Iynges are described in terms of whirling or rushing movement. Majercik, Chaldean, 175, understands the expression a oimh $k \&$ s tr of a kig $\mathbf{g i}$ in Frg. 87 to convey the image of the Iynges as moving out from and back towards the Father in a ceaseless, circular motion, and compares this to $s$ t r ok a I on in Frg. 206, which refers to Hecate's "magic wheel," from whence the divinatory connotations of turning wheels. Such divinatory activity is likely to have been present in oral tradition in the ANE for many centuries.

29 Devorah Dimant, Pseudo-Prophetic Texts, part 4 of Parabiblical Texts, vol. 21 of Qumran Cave 4, ed. Devorah Dimant, DJD 30 (Oxford: Clarendon Press, 2001), 18.

30 Dimant, Pseudo-Prophetic, 44. See Annette H. M. Evans, "To What Extent is Ezekiel the Source of Resurrection of the Dead in 4385 Pseudo-Ezekiel and Targum Ezekiel?” OTE 28 (2015), 83; Dimant, Pseudo-Prophetic, 36. 
9 the fac[es, one a lion, on]e an eagle, and one a calf, and one a man, and there wa[s a hand of]

10 a man joined from the backs of the living creatures and attached to [their wings ] and the whe[e]l[s,]

11 wheel joined to wheel as they went, and from the two sides of the whe[els were streams of fire]

In lines 6-7 there is a specific description of the manner of locomotion of each living being on two legs which is not present in Ezek 1 and 10 (Ezek 1:7 simply states “Their legs were straight," but does not elaborate on their manner of locomotion). ${ }^{31}$ In Pseudo-Ezekiel the detail of walking on two legs is clearly specified in more detail: "backwards, upon two each living creature was walking [and its two legs upon ...].” The specific term describing the manner of locomotion, אחור "backwards" in line 7, is not present in either Ezek 1 or 10. Dimant inserts a semi-colon after "backwards," thereby linking the word to the previous lacuna which follows on the reconstructed "and while walking they would not turn.” In the absence of any other evidence, Dimant's punctuation is accepted. Thus, here the word אחור counteracts the possibility indicated in Ezek 1:14 of understanding the movement as turning back as in Ezek 1:14, or rotational as in Codex Alexandrinus. The Pseudo-Ezekiel description supports the rabbinic problem of relating the emphasis on "not turning" to a contradiction of Ezek 1:14 (which hints that the living beings do actually turn in their movement). ${ }^{32}$ The significance of rotational movement as mentioned earlier was known to be connected to divination in the wider ANE cultural context. That in Pseudo-Ezekiel Ezek 1:14 is not represented, but counteracted, is in harmony with the denial of turning. It raises the suspicion that the author of Pseudo-Ezekiel was thinking along the same lines as the conservative translators who wanted to suppress the divinatory aspects of messenger activity in the Greek translation. Another telling detail is that in Ezek 10:14 the reader is expressly told that the living beings are none other than cherubim, and the bovine male face is replaced by that of a cherub placed first in the list, thus virtually labeling the four living beings as cherubs, yet in Pseudo-Ezekiel the cherubic aspect does not feature at all; in line 9, instead of the face of a cherub, there is the face of a man, as in Ezek $1 .{ }^{33}$ The galgali of Ezek 10 are also not

31 By implication, the deduction can be made that they were standing, which fits with the tradition of the attendants standing around the throne of God in the Divine Assembly, and also with the seraphim which were standing in Isa 6:2. One of the living creatures has a live coal in his hand. Dimant, Pseudo-Prophetic, 46, suggests that the association of fire in lines $11 \mathrm{~b}$ and 12 tends to confirm identification with the seraphs in Isa 6:2.

32 See $n .23$ above.

33 The editors of the OG reconstruction assumed that Ezek 10:14 was a later gloss, but it should be kept in mind that scarcely a hundred years later the verse was certainly present at Qumran (cf. n. 15). Cf. Lust, “Notes,” 30. 
mentioned at all in Pseudo-Ezekiel. Halperin notes that in Ezek 10 the ophanim are "raised above their literal meaning of 'wheels,"” and treated as a species of angelic being - in many ways resembling the cherubim. ${ }^{34}$ This impression is reinforced by the phrase "in my hearing" (Ezek 10:13) in combination with the definite article prefixed to galgal which implies that a living being is addressed, rather than just a mechanical object. Dimant notes "the author must have been well aware of the identification of the creatures as cherubim in Ezekiel 10.»35

An interesting addition in line 8a which is not present in Ezek 1 or 10, reinforces the earlier theme of resurrection and provides a hint of the idea of eternal life; the term נשמתה. Dimant notes that in the contemporary Mishnaic Hebrew, נשממה meant "soul."36 It could be understood in the usual biblical sense of "spirit," corresponding to the terms הרוח and רוח החיה at Ezek $1: 20$ and 21 respectively, but if that is what was meant, why then did the author not simply use $ח$, as in Ezekiel 1 ? $^{37}$

\section{E DISCUSSION}

Dimant expresses surprise that Pseudo-Ezekiel makes so little use of the parallel verses of the merkebah vision in Ezek 10, because Ezek 10 was certainly present at Qumran. ${ }^{38}$ It must be acceded that all the phrases in Pseudo-Ezekiel which could possibly be derived from Ezek 10 were already present in Ezek 1, therefore nothing in Pseudo-Ezekiel was necessarily derived from Ezek 10. An obvious conclusion would be that the model was LXX Ezek 1 without v. 14, as in the OG reconstruction, and without referring to Ezek 10. However, I see the absence rather as an indication of a conservative author,

34 David J. Halperin, “The Exegetical Character of Ezekiel 10:9-17,” VT 26 (1976): 136. Interestingly, in Pseudo-Ezekiel the face of the man is mentioned last in the list. The negative connotation for the rabbi's may have been because cherubim were intimately connected to the pharaonic throne. Devorah Dimant, "Hebrew Pseudepigrapha at Qumran,” in Old Testament Pseudepigrapha and the Scriptures, ed. Eibert J. C. Tigchelaar (Leuven: Peeters, 2014), 93, notes that Pseudo-Ezekiel includes anti-Egyptian polemic.

35 Dimant, Pseudo-Prophetic, 51.

36 Dimant, Pseudo-Prophetic, 46. Cf. William L. Holladay, A Concise Hebrew and Aramaic Lexicon of the Old Testament (Leiden: Brill, 1988), 248: "blowing (of God's breath) 2:S 22:18; breath, 1K17:17 everything that has breath”; Ludwig Koehler \& Walter Baumgartner, Lexicon in Veteris testament Libros (Leiden: Brill 1958), 639640: "blast, breath, every breathing thing, breath of life (Gen 2,7), the breathing things, souls (Js 57, 16), breath of God."

37 Eibert Tigchelaar, "Conceptualizing Spirit in the Dead Sea Scrolls: Between Philology and Religious Studies,” (paper presented at the IOSOT conference, Stellenbosch, 5 September 2016), has noted that "the concept of spirit has become much more essential and complex in many of the scrolls," one example being the conceptualisation of spirit as "more like an indiscrete force."

38 Dimant, Pseudo-Prophetic, 50, 51. 
because in Ezek 10 the angelic activity is not only explicit, but contains traces of divinatory associations in the use of galgali. The OG version of Ezek 10 has underlying indications that the word galgal carries associations with divination that were undesirable for conservative Jews. Throughout Pseudo-Ezekiel the word "ophanim" is used for "wheels" - there is no mention of galgali. In Pseudo-Ezekiel the avoidance of the loaded term galgali in combination with the completely novel specification of a manner of a manner of locomotion (backward) which would eliminate turning, tends to confirm my argument that the author of Pseudo-Ezekiel was conservative.

Pseudo-Ezekiel avoids any hint of earlier divinatory or magical practices associated with the activity of the living/spiritual beings. For instance hashmal, twice mentioned in Ezek 1 as intimately associated with the Deity, and which has associations connected to ANE magical practices, is not mentioned in Pseudo-Ezekiel at all. ${ }^{39}$ The nearest association with hashmal is in line 6: "a radiance of a chariot,” נגה מרכבה, yet the term מרכבה is not present in either Ezek 1 or $10 .{ }^{40}$

On the other hand, the situation of the "Dry Bones" vision from Ezek 37:1-14 and the "Merkebah" vision in Ezek 1 and 10 placed in direct sequence in Frg. 6 demands exploration of the author's intention. It has been clearly recognised that Pseudo-Prophetic texts attempted to appropriate prophetical authority. ${ }^{41}$ In the specification that the living beings walked backwards, thereby reinforcing the denial of turning, and the elimination of the cosmological, divinatory, and cherubim aspects, the deuteronomistic prohibition of divination might have been a motivating factor. Dimant suggests that the merkebah description in Pseudo-Ezekiel used the model as found in Ezek 43:1-9 which alludes back to Ezekiel's original vision in Ezek 1. She notes that in reworking Ezekiel's best-known canonical visions the author leans on Ezekiel's prophetical authority, and she recognises a coherent sequence in Pseudo-Ezekiel based on the outline of Ezek 37-43, but this sequence assigns all these scenes to the final, redemptive era. ${ }^{42}$ In this rewritten DSS text, per-

39 See Annette H. M. Evans, "Magical נחשתת and Mystical חשממל: Two Sides of the Same Ancient Near Eastern Coin?” JSEM 22 (2013): 164. Hashmal is translated as electron in the LXX, and amber in the KJV. See n.2 (Livingstone). Also see Annette H. M. Evans, “"As for the Wheels, It Was Cried unto Them in My Hearing, O Wheel': Angelological and Divinatory Connections in Ezekiel 10:13,” JSEM 21 (2012): 233.

40 Dimant, Pseudo-Prophetic, 46, notes that as early as ca.190-175 BCE, Ben Sira 49.8 uses the term Merkebah as a technical term for Ezekiel's visions.

41 Mladen Popovic, "Prophet, Books and Texts: Ezekiel, Pseudo-Ezekiel and the Authoritativeness of Ezekiel Traditions in early Judaism," in Authoritative Scriptures in Ancient Judaism, ed. Mladen Popovic (Leiden: Brill, 2010), 249. See Devorah Dimant "Hebrew Pseudepigrapha," 92-96, especially 96 (92-96 takes issue with Popovic (n. 18), on the issue of eschatology).

42 Dimant, Pseudo-Prophetic, 46, 51. 
haps an attempt at keeping the reputation of the Jewish faith on the straight and narrow, any hint of the earlier history of polytheism is suppressed, thereby facilitating the introduction of a new idea.

\section{F CONCLUSION}

In his introduction to his translation of the Targum to Ezekiel, Levey observes that Ezekiel rescued the Jewish nation from a sense of hopelessness by giving them a new vision of how God could be present with them in their new disastrous situation in terms of national restoration. ${ }^{43}$ It seems that almost half a millennium later, after yet another national blow, the apparently conservative Pseudo-Ezekiel author was concerned with a further development of the concept of hope. ${ }^{44}$ I would like to suggest that the author of Pseudo-Ezekiel minimises the association of traditional ANE activity of divination in Ezek 1 and 10 as the source of communication between God and the Israelite nation, and introduces the novel description "backwards" to reinforce that. Nevertheless, in spite of his conservatism, the author borrows the current Mishnaic meaning of the term נשממה as "soul," even though tinged with the dualism of the larger cultural context, in order to introduce an alternative eschatological concept. ${ }^{45}$ Thereby Pseudo-Ezekiel contributes to the establishment of the fulcrum on which the idea of resurrection becomes a reward for individual piety.

Clines pointed out that when an ancient text contains "indeterminacy of meaning” it is the interpretative community and its authority which plays a role in the reception of the particular interpretation. ${ }^{46}$ Here in Pseudo-Ezekiel, where the author maintains a conservative stance whilst introducing a new idea, so in his work Spangenberg calls on the interpretative community and its authority to open up the possibility of affirming the creative continuity of our various, diverse traditions to discover the shared epistemic resources for problem solving in the future. ${ }^{47}$ Just as the author of Pseudo-Ezekiel realized

43 Samuel H. Levey, The Targum of Ezekiel: Translated, with a Critical Introduction, Apparatus, and Notes (Edinburgh: T\&T Clark Ltd, 1987), 3. See Evans, “To What Extent?” 71, 80, 84.

44 Cf. Dimant, Pseudo-Prophetic, 16. Dimant suggests that Pseudo-Ezekiel was written during the devastating reign of Antiochus IV Epiphanes (175-164 BCE).

45 There is no indication in Pseudo-Ezekiel of what form resurrection would take, but the dualist Hellenistic concept of "soul" opens up the possibility of individual restoration.

46 Clines “A World established on Water (Psalm 24)”, 85.

${ }^{47}$ Cf. Wentzel van Huyssteen. The Shaping of Rationality, Towards Interdisciplinarity in theology and Science (Grand Rapids, Michigan: William B. Eerdmans Publishing Company, 1999), 284-2855, points out that we need to allow ourselves to freely and critically explore the experiential and interpretive roots of all our beliefs in our various domains of knowledge. To find coherence we must move beyond the kind 
that faith has to evolve, so this realisation has become increasingly clear in the work of Sakkie Spangenberg. ${ }^{48}$ The unflinching search for truth that has given us phenomenal advances in science is evident in his work too. For this, I salute him.

\section{BIBLIOGRAPHY}

Annus, Amar. The God Ninurta in the Mythology and Royal Ideology of Ancient Mesopotamia. Helsinki: University of Helsinki Neo-Assyrian Text Corpus Project, Institute for Asian and African Studies, 2002.

Bowker, John. The Targums and Rabbinic Literature. Cambridge: Cambridge University Press, 1969.

Clines, David J. A. "A World established on water (Psalm 24): Reader-Response, Deconstruction and bespoke Interpretation." Pages 79-90 in The New Literary Criticism and the Hebrew Bible. Edited by David J. A. Clines and J. Cheryl Exum. Sheffield: Sheffield Academic Press, 1995.

Cook, Johann. The Septuagint of Proverbs - Jewish and/or Hellenistic Proverbs? Concerning the Hellenistic Colouring of LXX Proverbs. Leiden: E. J. Brill, 1997.

Dimant, Devorah. Pseudo-Prophetic Texts. Part 4 of Parabiblical Texts. Edited by Devorah Dimant. Vol. 21 of Qumran Cave 4. DJD 30. Oxford: Clarendon Press, 2001. . "Hebrew Pseudepigrapha at Qumran.” Pages 89-104 in Old Testament Pseudepigrapha and the Scriptures. Edited by Eibert Tigchelaar. Leuven: Peeters, 2014.

Dimant, Devorah and John Strugnell. “The Merkebah Vision in Second Ezekiel.” RevQ 14 (1990): 331-348.

Eichrodt, Walther. Ezekiel, A Commentary. Translated by Cosslett Quinn. London: SCM Press, 1970.

Evans, Annette H. M. “The Development of Jewish Beliefs in Angels: Egyptian and Hellenistic Connections ca. 600 BCE.-200 CE.” D Phil diss., University of Stellenbosch, 2007. . "'As for the Wheels, It was Cried unto Them in my Hearing, O Wheel': Angelological and Divinatory Connections in Ezekiel 10:13.” JSEM 21/2 (2012): 222-236.

. "Magical נחשמל and Mystical Two Sides of the Same Ancient Near Eastern Coin?” JSEM 22/1 (2013): 163-176.

of fideism where our own unique experiences and appropriate explanations are never challenged. In order to be freed from being the fideistic prisoners of our preferred traditions and respective disciplines we must engage in genuine interdisciplinary conversation. Van Huyssteen asserts that a postfoundationalist Christian theology must maintain "a relentless criticism of our uncritically held crypto-foundationalist assumptions.”

${ }^{48}$ See for instance his comparison between "the author of Qoheleth who undermined the traditional wisdom paradigm, and the author of Ps 783 (who) tried to keep it intact." Izak Spangenberg, "Psalm 73 and the Book of Qoholeth," OTE 29 (2016): 151-175, 173. 
. "To What Extent is Ezekiel the Source of Resurrection of the Dead in 4Q385 Pseudo-Ezekiel and Targum Ezekiel?” OTE 28/1 (2015): 70-85. Doi: http://dx.doi.org/10.17159/2312-3621/2015/v28n1a6.

Fishbane, Michael. Biblical Interpretation in Ancient Israel. Oxford: Clarendon Press, 1985.

Fohrer, Georg. Ezechiel. Tubingen: Mohr Siebeck, 1955.

Freedy, Kenneth S. “The Glosses in Ez I - XXIV.” VT 20 (1970): 129-152.

Greenberg, Moshe. Ezekiel 1-20. AB. New York: Doubleday, 1983.

Halperin, David J. “The Exegetical Character of Ezekiel 10:9-17.” VT 26 (1976): 129141.

Holladay William L. A Concise Hebrew and Aramaic Lexicon of the Old Testament. Leiden: Bril, 1988.

Jellicoe, Sidney. The Septuagint and Modern Study. Oxford: Clarendon Press, 1968.

Kingsley, P. "Ezekiel by the Grand Canal: Between Jewish and Babylonian Traditions.” JRAS 3/2 (1992): 339-346.

Levey, Samuel H. The Targum of Ezekiel: Translated, with a Critical Introduction, Apparatus, and Notes. Edinburgh: T\&T Clark Ltd, 1987.

Lewy, Hans. The Chaldean Oracles. Paris: Etudes Augustineinnes, 1978.

Livingstone, Alasdair. Mystical and Mythological Explanatory Works of Assyrian and Babylonian Scholars. Oxford: Clarendon, 1986.

Lust, J. "The Use of Textual Witnesses for the Establishment of the Text: The Shorter and Longer Texts of Ezekiel: An Example: Ez. 7.” Pages 7-19 in Ezekiel and his Book. Edited by Johan Lust. Leuven: Uitgeverij Peters, 1986.

. "Translation Greek and the Lexicography of the Septuagint.” JSOT 59 (1993): 109-120.

. "Notes to the Septuagint Ezekiel 1 and 2.” ETL 75 (1999): 5-31.

. "The 'Rekenaar' and the Septuagint - LXx Ezekiel, A Case Study.” Pages

373-402 in Bible and Computer: The Stellenbosch AIB 1-6 Conference:

Proceedings of the Association Internationale Bible et Informatique "From

Alpha to Byte,” University of Stellenbosch 17-21 July, 2000. Edited by Johann Cook. Leiden: Brill, 2000.

Mach, Michael. "Entwicklungsstadion des jüdischen Engelglaubens in vorrabbinischer Zeit.” Tübingen: Mohr, 1992.

Magness, Jody. The Archaeology of Qumran and the Dead Sea Scrolls. Grand Rapids, MI: Williams B Eerdmans Publishing Company, 2002.

Majercik, Ruth. The Chaldean Oracles. Leiden: E J Brill, 1989.

Mullen, E. Theodore Jr. The Assembly of the Gods. HSM 24. Atlanta, GA: Scholars Press, 1980.

Patmore, Hector M. "The Shorter and Longer Texts of Ezekiel: The Implications of the Manuscript Finds from Masada and Qumran.” JSOT 32/2 (2007): 231-242.

Popovic, Mladen. "Prophet, Books and Texts. Ezekiel, Pseudo-Ezekiel and the Authoritativeness of Ezekiel Traditions in Early Judaism.” Pages 230-251 in Authoritative Scriptures in Ancient Judaism. Edited by Mladen Popovic. Leiden: Brill, 2010.

Sanders, James A. “Origen and the First Christian Testament.” Pages 134-142 in Studies in the Hebrew Bible, Qumran, and the Septuagint Presented to Eugene 
314 Evans, “Ezekiel’s ‘Living Beings,”” OTE 30/2 (2017): 300-314

Ulrich. Edited by Peter W. Flint, Emanuel Tov and James C. VanderKam. Leiden: Brill, 2006.

Sanderson, Judith E. The Prophets. Vol. 10 of Qumran Cave 4. Edited by Eugene Ulrich, Frank Moore Cross, Russell E. Fuller, Judith E. Sanderson, Patrick W. Skehan and Emanuel Tov. Oxford: Clarendon, 1997.

Spangenberg, Izak J. J. "Psalm 24: Reading from Right to Left and from Back to Front," OTE 24/3 (2011):746-766.

"The Spotlight on Genesis 1-3: A Report on Shifts in Mindset and Beliefs," OTE 27/2 (2014): 612-636.

'Psalm 73 and the Book of Qoholeth,' OTE 29/1 (2016): 151-

75, 173. Doi: http://dx.doi.org/10.17159/2312-3621/2016/v29n1a10.

Tigchelaar, Eibert J. C., ed. Old Testament Pseudepigrapha and the Scriptures. Leuven: Peeters, 2014.

Tov, Emmanuel. The Text-Critical use of the Septuagint in Biblical Research. Jerusalem: Simor Ltd, 1981.

Uehlinger, Christopher and Susanne Müller Trufaut. "Ezekiel 1, Babylonian Cosmological Scholarship and Iconography: Attempts at Further Refinement.” Theologische Zeitschrift 2/57 (2001): 140-171.

Ziegler, Joseph, ed. Ezekiel. Vol. 16/1 of Septuaginta Vetus Testamentum Graecum. Edited by Joseph Ziegler. Gottingen: VandenHoeck \& Ruprecht, 1977.

Zimmerli, Walther. Ezekiel 1: Chapters 1-24. Hermeneia. Philadelphia: Fortress Press, 1979. . The Fiery Throne: The Prophets and Old Testament Theology. Minneapolis: Fortress Press, 2003.

Dr. Annette Evans, Research Associate, University of the Free State. Email: ahmevans@gmail.com. 